\title{
Comparison of tobacco control policies in the Eastern Mediterranean countries based on tobacco control scale scores
}

G. Heydari, ${ }^{1}$ F. Talischi, ${ }^{2}$ M.R. Masjedi, ${ }^{2}$ H. Alguomani, ${ }^{3}$ L. Joossens ${ }^{3}$ and M.Ghafari ${ }^{4}$

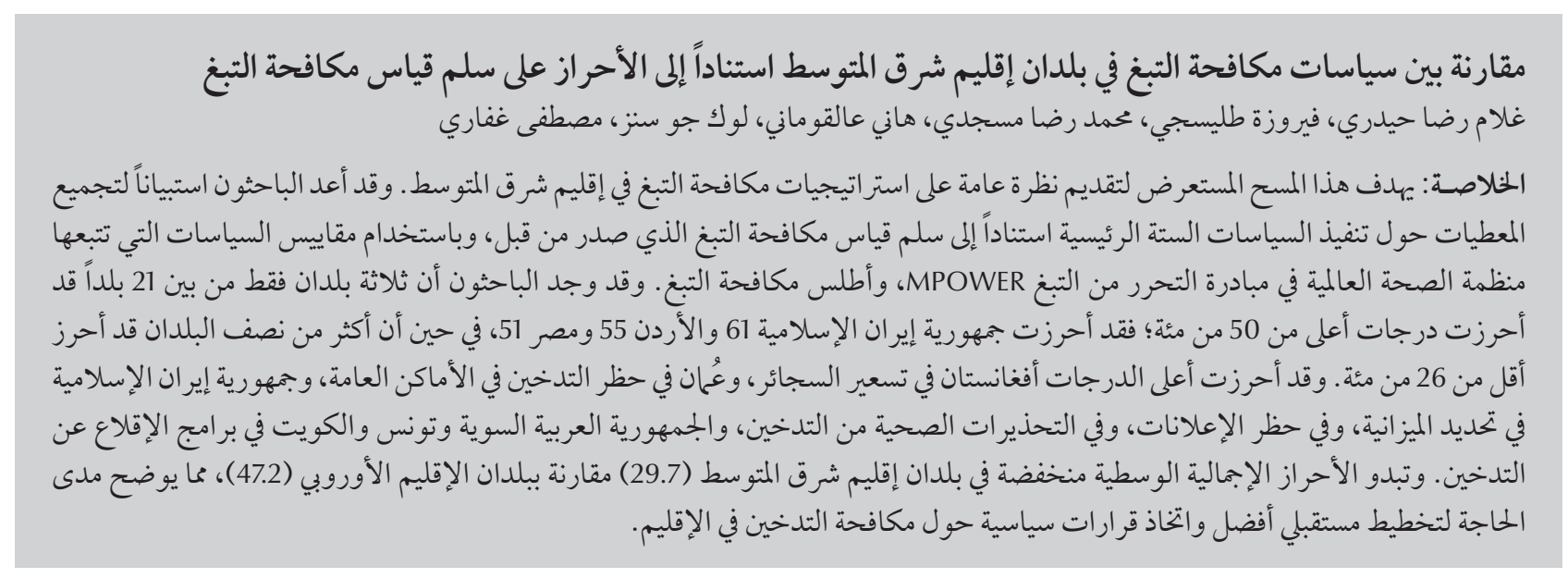

ABSTRACT This cross-sectional survey aimed to provide an overview of tobacco control strategies in the countries of the Eastern Mediterranean Region (EMR). A questionnaire to collate data on implementation of 6 major policies was developed based on the previously published Tobacco Control Scale and using MPOWER measures of the WHO Tobacco Free Initiative and the Tobacco Atlas. Only 3 of the 21 countries scored higher than 50 out of 100: Islamic Republic of Iran (61), Jordan (55) and Egypt (51). More than half of countries scored less than 26. Highest scores were achieved by Afghanistan in cigarette pricing, Oman in smoking bans in public places, Islamic Republic of Iran in budgeting, prohibition of advertisements and health warnings against smoking and Syrian Arab Republic, Tunisia and Kuwait in tobacco cessation programmes. The low mean total score in EMR countries (29.7) compared with European countries (47.2) highlights the need for better future planning and policy-making for tobacco control in the Region.

\begin{abstract}
Comparaison des politiques de lutte antitabac dans les pays de la Méditerranée orientale à partir des scores à l'échelle de lutte antitabac

RÉSUMÉ La présente enquête transversale visait à fournir une vision globale des stratégies de lutte antitabac dans les pays de la Région de la Méditerranée orientale. Afin de recueillir des données sur la mise en ouvre de six politiques principales, un questionnaire a été élaboré à partir de l'échelle précédemment publiée intitulée Tobacco Control Scale, des mesures MPOWER de l'Initiative Pour un monde sans tabac de l'Organisation mondiale de la Santé et de l'Atlas du tabac. Seuls 3 pays sur 21 ont obtenu un résultat supérieur à 50 sur 100 : la République islamique d'Iran (61), la Jordanie (55) et l'Égypte (51). Plus de la moitié des pays ont obtenu des résultats inférieurs à 26. Les scores les plus élevés ont été obtenus par l'Afghanistan pour la tarification des cigarettes, par Oman pour les interdictions de fumer dans les lieux publics, par la République islamique d'Iran pour la budgétisation, l'interdiction de la publicité et les mises en garde sanitaires contre le tabagisme et par le Koweït, la République arabe syrienne et la Tunisie pour leurs programmes de sevrage tabagique. Le faible score moyen total des pays de la Méditerranée orientale $(29,7)$ par rapport aux pays européens $(47,2)$ souligne la nécessité d'améliorer à l'avenir la planification et l'élaboration des politiques de lutte antitabac dans la Région.
\end{abstract}




\section{Introduction}

Over a number of years, many efforts have been made to prevent and control tobacco use, culminating in the World Health Organization Framework Convention on Tobacco Control (WHO FCTC). This was the world's first global public health and corporate accountability treaty, adopted by the World Health Assembly in May 2003. To date 168 countries are signatories to the Treaty [1]. Many articles in this agreement provide basic tools for countries to enact comprehensive tobacco control legislation. These were encapsulated in the World Bank report of 2003 [2], which listed the 6 most effective tobacco control measures as:

- Higher taxes on cigarettes and other tobacco products.

- Bans on smoking in public and work places: schools, health facilities, public transport, restaurants, cinemas, etc.

- Comprehensive bans on advertising and promotion of all tobacco products, logos and brand names.

- Better consumer information: counter-advertising, media coverage, research findings.

- Large, direct warning labels on cigarette boxes and other tobacco products.

- Help for smokers who wish to quit, including increased access to nicotine replacement and other cessation therapies.

In 2006 Joossens and Raw developed the Tobacco Control Scale, using these criteria to develop 6 indicators for assessing the implementation of tobacco control programmes in 30 European countries [3]. The study reported here is the first study to compare the tobacco control activities in all countries in the Eastern Mediterranean Region (EMR) region. The main objective of this study was to obtain an overview of tobacco control strategies in EMR. We took the European study as our model, using data principally from MPOWER [4] and the Tobacco atlas [5]. It was hoped that the study would provide evidence for policy-makers about the implementation of tobacco control policies in the region and act as stimulus for a change.

\section{Methods}

A cross-sectional survey was used to collate data about implementation of tobacco control regulations in $21 \mathrm{EMR}$ countries (excluding Palestine). A datasheet covering the 6 main indicators of tobacco control programmes was designed, based on the tool developed by Joossens and Raw [3]. In view of the lack of data from some of the countries the revised datasheet omitted certain variables regarding the rules on banning smoking in public places and the conditions for tobacco cessation services. In the original study the questionnaire was sent to correspondents from the European Network for Smoking Prevention in each country for completion [3]. For the current study data were obtained from the MPOWER package of 2008 (WHO Tobacco Free Initiative) [4], the Tobacco atlas of 2009 (American Cancer Society/World Lung Foundation) [5], and the World development report 2008 (World Bank) [6].

The 6 indicators used in the scale were as follows:

- Price of cigarettes (max. score 30). Cigarette prices were calculated as the price of a packet of 20 cigarettes (Marlboro and most popular local brand), adjusted for gross domestic product (GDP) per capita. The country with the highest prices was awarded 15 points, the next highest 14 points, and so on.

- Tobacco smoke-free public places (max. score 22). Legislation for smoke-free public places was scored for workplaces, cafés and restaurants and other public places. Scores were then adjusted for the degree of enforcement of regulations in that country.

- National budget for tobacco control activities (max. score 15). The reported national budget for tobacco control activity was adjusted for GDP per capita. Scores were assigned to countries in decreasing budget rank order of 15,14 , etc.

- Prohibition of tobacco advertising and promotion (max. score 13). Bans on tobacco advertising were scored according to location of ban: on television, outdoor advertising, print media, indirect advertising, point of sale advertising, cinema advertising, sponsorship, Internet advertising and radio advertising. Scores were adjusted for level of enforcement.

- Health warning labels on tobacco packets (max. score 10). Health warnings were scored based on size and whether they were rotating, in picture format and in colour.

- Provision of smoking cessation support (max. score 10). Treatment for smoking cessation was scored for availability of nicotine substitutes and bupropion and reported availability of services in primary care facilities, in hospitals, from health professionals or in the community.

Law enforcement factors were obtained from the MPOWER 2008 guidebook [4] and are expressed out of 10 points. More details of the scoring are shown on the tables. The total maximum score for a country was 100 .

The revised questionnaire was evaluated and approved by experts at the Tobacco Control Research Centre at Shahid Beheshti University of Medical Sciences. After data collection the preliminary raw information was sent to an international consultant for review and the final data were reviewed and approved by the secretary general of the Iranian Anti-Tobacco Association and head of the National Committee on Tobacco Control from the Iranian Ministry of Health. 
The data for the 6 indicators were tabulated separately and as total scores for all 21 EMR countries.

\section{Results}

The scores of each of the 6 major policy indicators in the 21 EMR countries are shown in Tables 1-6.

Afghanistan scored highest for tobacco pricing in relation to GDP, with 26 points out of 30 (Table 1). Pakistan, Morocco, Sudan and Tunisia also scored reasonably high. The United Arab Emirates, Qatar and Kuwait scored the lowest, although data on prices were for unavailable for Djibouti, Somalia and Libya.
Oman scored higher than other countries for regulations and enforcement of bans on smoking in public places $(11.2 / 22.0)$, followed closely by the Islamic Republic of Iran (11.0) (Table 2). While many countries had regulations in place, the low enforcement factor in some countries meant that 10 countries scored zero on this indicator.

The Islamic Republic of Iran had the top score on budgeting for tobacco control activities in relation to GDP (15 points), followed by Saudi Arabia and Pakistan (14 and 13 respectively) (Table 3). The lowest scoring country was Qatar. A national budget for tobacco control, however, could not be established for 8 countries.
The Islamic Republic of Iran also scored highest in prohibition and enforcement of tobacco advertising 13.0/13.0, followed by the Syrian Arab Republic at 12.0 and Djibouti at 11.7 (Table 4).

Placement of health warnings on cigarette packets again showed the Islamic Republic of Iran in top place (10/10), with Djibouti and Egypt scoring well (Tables 5). There were 13 countries that scored zero on this indicator.

Syrian Arab Republic, Tunisia and Kuwait had the best provision of smoking cessation services, each 9/10, while Pakistan, Saudi Arabia, Somalia and Yemen scored zero (Table 6).

\begin{tabular}{|c|c|c|c|c|c|c|c|c|}
\hline \multirow[t]{2}{*}{ Country } & \multicolumn{2}{|c|}{ Price (US\$) ${ }^{\mathrm{a}}$} & \multirow{2}{*}{$\begin{array}{c}\text { GDP per } \\
\text { capita } \\
(\text { US\$) }\end{array}$} & \multicolumn{2}{|c|}{ Points $^{c}$} & \multicolumn{2}{|c|}{ Price score ${ }^{\mathrm{d}}$} & \multirow[t]{2}{*}{ Total score } \\
\hline & Marlboro & $\begin{array}{l}\text { Local } \\
\text { brand }\end{array}$ & & Marlboro & $\begin{array}{l}\text { Local } \\
\text { brand }\end{array}$ & Marlboro & $\begin{array}{l}\text { Local } \\
\text { brand }\end{array}$ & \\
\hline Afghanistan & 0.40 & 0.40 & 416 & 9.61 & 9.61 & 12 & 14 & 26 \\
\hline Bahrain & 1.45 & 1.45 & 27248 & 5.32 & 5.32 & 6 & 7 & 13 \\
\hline Djibouti & - & - & 1252 & - & - & - & - & - \\
\hline Egypt & 1.33 & 1.28 & 2162 & 6.15 & 5.92 & 9 & 8 & 17 \\
\hline Iran (IR) & 1.82 & 0.48 & 4600 & 3.95 & 1.04 & 4 & 2 & 6 \\
\hline Iraq & 1.50 & 1.00 & 3007 & 4.98 & 3.32 & 5 & 6 & 11 \\
\hline Jordan & 2.01 & 7.06 & 3626 & 5.81 & 19.47 & 8 & 10 & 18 \\
\hline Kuwait & 1.68 & 3.00 & 45920 & 0.36 & 0.65 & 1 & 1 & 2 \\
\hline Lebanon & 1.44 & 1.65 & 7708 & 1.86 & 2.14 & 3 & 4 & 7 \\
\hline Libya & - & - & 14479 & - & - & - & & - \\
\hline Morocco & 3.92 & 1.80 & 2827 & 13.86 & 6.36 & 14 & 10 & 24 \\
\hline Oman & 1.84 & 1.59 & 21646 & 0.85 & 0.73 & 1 & 1 & 2 \\
\hline Pakistan & 1.16 & 0.86 & 1022 & 11.35 & 8.41 & 13 & 12 & 25 \\
\hline Qatar & 1.35 & 1.35 & 93204 & 0.14 & 0.14 & 1 & 1 & 2 \\
\hline Saudi Arabia & 1.51 & 3.00 & 18855 & 0.80 & 1.59 & 1 & 3 & 4 \\
\hline Somalia & - & - & - & - & - & - & & - \\
\hline Sudan & 2.40 & 0.96 & 1522 & 5.76 & 6.30 & 15 & 9 & 24 \\
\hline Syria & 1.56 & 0.68 & 2768 & 5.63 & 2.45 & 7 & 5 & 12 \\
\hline Tunisia & 3.54 & 3.88 & 3955 & 8.95 & 9.60 & 11 & 13 & 24 \\
\hline UAE & 1.63 & 1.48 & 55028 & 0.29 & 0.26 & 1 & 1 & 2 \\
\hline Yemen & 0.82 & 0.82 & 1171 & 7.00 & 7.00 & 10 & 11 & 21 \\
\hline Max. score & - & - & - & - & - & 15 & 15 & 30 \\
\hline
\end{tabular}

${ }^{a}$ Price of packet of 20 Marlboro ${ }^{\circledR}$ brand cigarettes and 20 most popular local brand cigarettes. Source: Tobacco atlas, 2009 [5]. ${ }^{b}$ Gross domestic product (GDP) per capita. Source: World Bank, 2008 [6]. 'Price of 20 cigarettes/GDP per capita $\times 10$ 000. ${ }^{d}$ Country with highest price ratio receives 15, followed by $14,13,12$, etc. Prices are in US\$ at 2009 official exchange rates.

Dash (-) indicates data unavailable. 


\begin{tabular}{|c|c|c|c|c|c|}
\hline Country & Workplaces $^{\mathrm{a}}$ & $\begin{array}{l}\text { Cafés and } \\
\text { restaurants }\end{array}$ & $\begin{array}{c}\text { Other public } \\
\text { places }^{c}\end{array}$ & Enforcement $^{\mathrm{d}}$ & Total score ${ }^{\mathrm{e}}$ \\
\hline Afghanistan & 0 & 0 & 0 & 0.0 & 0.0 \\
\hline Bahrain & 10 & 0 & 4 & 0.3 & 4.2 \\
\hline Djibouti & 0 & 0 & 4 & 0.0 & 0.0 \\
\hline Egypt & 10 & 0 & 4 & 0.3 & 4.2 \\
\hline Iran (IR) & 10 & 8 & 4 & 0.5 & 11.0 \\
\hline Iraq & 0 & 0 & 0 & 0.0 & 0.0 \\
\hline Jordan & 10 & 0 & 4 & 0.4 & 5.6 \\
\hline Kuwait & 10 & 4 & 4 & 0.5 & 9.0 \\
\hline Lebanon & 0 & 0 & 0 & 0.0 & 0.0 \\
\hline Libya & 10 & 0 & 4 & 0.1 & 1.4 \\
\hline Morocco & 10 & 0 & 4 & 0.0 & 0.0 \\
\hline Oman & 10 & 0 & 4 & 0.8 & 11.2 \\
\hline Pakistan & 10 & 0 & 4 & 0.2 & 2.8 \\
\hline Qatar & 0 & 0 & 0 & 0.0 & 0.0 \\
\hline Saudi Arabia & 10 & 0 & 4 & 0.0 & 0.0 \\
\hline Somali & 0 & 0 & 4 & 0.3 & 1.2 \\
\hline Sudan & 10 & 0 & 4 & 0.0 & 0.0 \\
\hline Syria & 0 & 0 & 0 & 0.0 & 0.0 \\
\hline Tunisia & 0 & 0 & 0 & 0.0 & 0.0 \\
\hline UAE & 10 & 0 & 4 & 0.3 & 4.2 \\
\hline Yemen & 10 & 0 & 4 & 0.2 & 2.8 \\
\hline Max. score & 10 & 8 & 4 & 1.0 & 22.0 \\
\hline
\end{tabular}

${ }^{a}$ Workplaces excluding cafes and restaurants (one only of): complete ban without exceptions (no smoking rooms), enforced = 10; complete ban, but with closed, ventilated, designated smoking rooms, enforced $=8$; complete ban, but with ventilated, designated smoking rooms, enforced =6; meaningful restrictions, enforced $=$ 4; legislation, but not enforced $=2 .{ }^{b}$ Cafes and restaurants (one only of): complete ban, enforced = 8 ; complete ban, but with closed, ventilated, designated smoking rooms, enforced $=6$; meaningful restrictions, enforced $=4$; legislation, but not enforced $=2 .{ }^{c}$ Public transport and other public places (additive): complete ban in domestic trains, without exceptions = 1; complete ban in other public transport, without exceptions = 1; complete ban in educational, health, government and cultural places, without exceptions $=2$ OR ban in educational, health, government and cultural places, but with designated smoking areas or rooms $=1{ }^{d}$ Law enforcement factor. ${ }^{e}$ Total $=$ score $\times$ enforcement factor. Source: MPOWER, 2008 [4].

The total scores for all 6 indicators are presented on Table 7. The highest score achieved was 61 points out of 100 (Islamic Republic of Iran). Only 3 countries scored higher than 50 points (Islamic Republic of Iran, Jordan and Egypt), 5 countries scored below 20 and 2 countries (Somalia and Libya) had scores of just over 1 point. The mean score of the countries in the EMR was 29.7 (SD 3.6) and the median was 26 points.

\section{Discussion}

Since 2007, the Tobacco Prevention and Control Research Centre in Tehran has been working as a WHO collaborating centre in the EMR. The main responsibility of this centre is not only to implement national programmes but also to evaluate tobacco control programmes in EMR. One of its unique activities has been a comparison of indicator scores for tobacco control programmes in countries within the same region in order to monitor and compare the countries' tobacco control programmes.

The scale developed for this survey was a modification of the previously published Tobacco Control Scale [3]. As the data were extracted from sources such as MPOWER measures and the Tobacco Atlas they may not cover all important variables and the results therefore may not be conclusive. Further studies will determine the strengths and shortcomings of this scale in the hope of developing improved tobacco control policy indicators in the future. Nevertheless, the survey has provided useful preliminary data and it is hoped that the results will stimulate countries to fill the gaps in their tobacco control programmes and to strengthen their areas of effective action. The study could be repeated with updated data, so that the changes in countries' activities are monitored over time. This could motivate them to strive for improvements in the implementation of their tobacco control programmes.

The mean total score for tobacco control activity in the EMR countries 


\begin{tabular}{|c|c|c|c|c|}
\hline Country & $\begin{array}{l}\text { National budget } \\
\text { (US\$) }\end{array}$ & $\begin{array}{l}\text { GDP per capitab } \\
\text { (US\$) }\end{array}$ & Points ${ }^{c}$ & Total score ${ }^{d}$ \\
\hline Afghanistan & - & 416 & - & - \\
\hline Bahrain & - & 27248 & - & - \\
\hline Djibouti & 2926 & 1252 & 233.7 & 4 \\
\hline Egypt & 12500 & 2162 & 578.2 & 9 \\
\hline Iran IR & 2000000 & 4600 & 43478.3 & 15 \\
\hline Iraq & - & 3007 & - & - \\
\hline Jordan & 93986 & 3626 & 2592.0 & 11 \\
\hline Kuwait & 181638 & 45920 & 395.6 & 8 \\
\hline Lebanon & 30000 & 7708 & 389.2 & 7 \\
\hline Libya & - & 14479 & - & - \\
\hline Morocco & - & 2827 & - & - \\
\hline Oman & 84211 & 21646 & 389.0 & 6 \\
\hline Pakistan & 82960 & 1022 & 8091.0 & 13 \\
\hline Qatar & 96978 & 93204 & 104.0 & 3 \\
\hline Saudi Arabia & 2540107 & 18855 & 13471.8 & 14 \\
\hline Somali & - & - & - & - \\
\hline Sudan & 4421 & 1522 & 290.5 & 5 \\
\hline Syria & 133690 & 2768 & 4829.8 & 12 \\
\hline Tunisia & - & 3955 & - & - \\
\hline UAE & - & 55028 & - & - \\
\hline Yemen & 25000 & 1171 & 2134.9 & 10 \\
\hline Max. score & - & - & - & 15 \\
\hline
\end{tabular}

${ }^{a}$ Tobacco control spending by the government. Source: MPOWER, 2008 [4]. ${ }^{b}$ Gross domestic product (GDP) per capita. Source: World Bank, 2008 [6]. ${ }^{c}$ GDP per capita $\times 100 .{ }^{d}$ Country with highest points receives 15 , followed by $14,13,12$, etc.

Prices are in US\$ at 2009 official exchange rates.

Dash (-) indicates data unavailable.

(29.7/100) was considerably lower than in countries in the European region (47.2/100) [3]. Although there were some slight differences in the scoring systems used between the 2 surveys, this comparison is valuable. Moreover, our data revealed total scores of less then 26 for more than half of the countries in EMR, a finding which should be taken seriously by the responsible governments. Only 3 out of 21 countries - Islamic Republic of Iran (61), Jordan (55) and Egypt (51)—scored above 50, which is disappointing compared with the situation in Europe where 11 out of 30 scored over 50 points [3].

One outcome of our survey was to highlight differences in enforcement of regulations across the countries. For example, the Islamic Republic of Iran, which had the highest total score for tobacco control activities, had the lowest score among all the countries for implementing measures to increase cigarette prices. The country therefore needs to focus on this issue in its tobacco control policy-making. Although Kuwait, Syrian Arab Republic and Tunisia had the highest scores in providing tobacco cessation services, they need to take action to enforce regulations about health warnings on cigarette packets.

Further interesting differences in tobacco control activities can be noted when comparing the scores of countries on each of the 6 policies. For example, the highest score on cigarette pricing was achieved by Afghanistan, although this may have been an artefact due to very low GDP in this country. High scores obtained by Oman for the indicator on banning smoking in public places could be attributed to the $80 \%$ law enforcement factor. Although the Islamic Republic of Iran achieved the highest score on smoking bans in public places, it performed badly on tobacco pricing. There were 8 countries whose tobacco control budget could not be evaluated due to incomplete records and 13 countries could not be scored on health warnings due to the absence of these on cigarette packages. Given that advertisements and sponsorship are fully banned in most of the EMR countries, scores for prohibition of tobacco advertising and sponsorship seemed to be appropriate. In contrast, EMR countries' provision of tobacco cessation services could be interpreted as better then expected.

In conclusion, the results of this survey performed for the first time in a single WHO region may prove useful for comparing and monitoring the tobacco control activity in other regions. The low overall score in EMR countries compared with European countries calls for better future planning and policymaking for tobacco control in the EMR. 


\begin{tabular}{|c|c|c|c|c|c|c|c|c|c|c|c|}
\hline Country & $\mathrm{TV}^{\mathrm{a}}$ & $\begin{array}{c}\text { Out } \\
\text { doors }^{b}\end{array}$ & Magazinesc & Indirect $^{\mathrm{d}}$ & $\begin{array}{l}\text { Point-of- } \\
\text { sale }^{\mathrm{e}}\end{array}$ & Cinema ${ }^{f}$ & $\begin{array}{l}\text { Sponsor- } \\
\text { shipg }^{8}\end{array}$ & Internet ${ }^{\text {h }}$ & Radio $^{i}$ & $\begin{array}{c}\text { Enforce- } \\
\text { ment }\end{array}$ & $\begin{array}{l}\text { Total } \\
\text { score }^{k}\end{array}$ \\
\hline Afghanistan & 1.5 & 2 & 1 & 0 & 0 & 0 & 0 & 0.0 & 0.5 & 0.0 & 0.0 \\
\hline Bahrain & 1.5 & 0 & 0 & 0 & 0 & 0 & 0 & 0.0 & 0.5 & 0.6 & 1.2 \\
\hline Djibouti & 3.0 & 2 & 2 & 2 & 1 & 1 & 1 & 0.5 & 0.5 & 0.9 & 11.7 \\
\hline Egypt & 3.0 & 2 & 2 & 2 & 0 & 0 & 1 & 0.0 & 0.5 & 1.0 & 10.5 \\
\hline Iran (IR) & 3.0 & 2 & 2 & 2 & 1 & 1 & 1 & 0.5 & 0.5 & 1.0 & 13.0 \\
\hline Iraq & 3.0 & 2 & 2 & 0 & 1 & 1 & 0 & 0.5 & 0.5 & 0.0 & 0.0 \\
\hline Jordan & 1.5 & 2 & 1 & 2 & 1 & 1 & 1 & 0.5 & 0.5 & 1.0 & 10.5 \\
\hline Kuwait & 1.5 & 2 & 1 & 2 & 1 & 1 & 1 & 0.0 & 0.5 & 0.9 & 9.0 \\
\hline Lebanon & 0.0 & 0 & 0 & 0 & 0 & 0 & 0 & 0.0 & 0.0 & 0.0 & 0.0 \\
\hline Libya & 1.5 & 2 & 1 & 0 & 0 & 0 & 0 & 0.0 & 0.0 & 0.0 & 0.0 \\
\hline Morocco & 3.0 & 2 & 2 & 0 & 0 & 1 & 1 & 0.0 & 0.0 & 0.0 & 0.0 \\
\hline Oman & 0.0 & 0 & 0 & 0 & 0 & 0 & 0 & 0.0 & 0.0 & 0.0 & 0.0 \\
\hline Pakistan & 0.0 & 0 & 0 & 0 & 0 & 0 & 0 & 0.0 & 0.0 & 0.0 & 0.0 \\
\hline Qatar & 1.5 & 2 & 1 & 2 & 1 & 1 & 1 & 0.0 & 0.5 & 0.8 & 8.0 \\
\hline Saudi Arabia & 1.5 & 2 & 1 & 1 & 0 & 1 & 0 & 0.0 & 0.5 & 0.5 & 3.5 \\
\hline Somali & 0.0 & 0 & 0 & 0 & 0 & 0 & 0 & 0.0 & 0.0 & 0.0 & 0.0 \\
\hline Sudan & 1.5 & 2 & 1 & 1 & 1 & 1 & 1 & 0.0 & 0.5 & 0.1 & 0.9 \\
\hline Syria & 3.0 & 2 & 2 & 2 & 1 & 0 & 1 & 0.5 & 0.5 & 1.0 & 12.0 \\
\hline Tunisia & 3.0 & 2 & 2 & 2 & 1 & 0 & 1 & 0.5 & 0.5 & 0.8 & 9.6 \\
\hline UAE & 1.5 & 2 & 1 & 2 & 1 & 1 & 1 & 0.0 & 0.5 & 0.4 & 4.0 \\
\hline Yemen & 3.0 & 2 & 2 & 2 & 1 & 1 & 1 & 0.5 & 0.5 & 0.5 & 6.5 \\
\hline Max. score & 3 & 2 & 2 & 2 & 1 & 1 & 1 & 0.5 & 0.5 & 1.0 & 13.0 \\
\hline
\end{tabular}

Points for each type of ban included (additive): ${ }^{a}$ Complete ban on tobacco advertising on television $=3 .{ }^{b}$ Complete ban on outdoor advertising (e.g. posters) $=2$. ${ }^{c}$ Complete ban on advertising in print media (e.g. newspapers and magazines) $=2 .{ }^{d}$ Complete ban on indirect advertising (e.g. cigarette branded clothes, watches, etc) $=$ 2. ${ }^{e}$ Ban on point of sale advertising $=1 .{ }^{f}$ Ban on cinema advertising $=1 .{ }^{g}$ Ban on sponsorship $=1 .{ }^{h}$ Ban on Internet advertising $=0.5$. ${ }^{i}$ Ban on radio advertising $=0.5$. ${ }^{i}$ Law enforcement factor. ${ }^{k}$ Total $=$ score $\times$ enforcement factor. Source: MPOWER, 2008 [4].

\begin{tabular}{|c|c|c|c|c|c|}
\hline Country & Size $^{a}$ & Rotating ${ }^{b}$ & Colourc & Picture $^{\mathrm{d}}$ & Total score \\
\hline Afghanistan & 0 & 0 & 0 & 0 & 0 \\
\hline Bahrain & 0 & 0 & 0 & 0 & 0 \\
\hline Djibouti & 4 & 0 & 1 & 3 & 8 \\
\hline Egypt & 4 & 0 & 1 & 3 & 8 \\
\hline Iran (IR) & 4 & 2 & 1 & 3 & 10 \\
\hline Iraq & 0 & 0 & 0 & 0 & 0 \\
\hline Jordan & 3 & 0 & 1 & 3 & 7 \\
\hline Kuwait & 0 & 0 & 0 & 0 & 0 \\
\hline Lebanon & 0 & 0 & 0 & 0 & 0 \\
\hline Libya & 0 & 0 & 0 & 0 & 0 \\
\hline Morocco & 0 & 0 & 0 & 0 & 0 \\
\hline Oman & 0 & 0 & 0 & 0 & 0 \\
\hline Pakistan & 0 & 0 & 0 & 0 & 0 \\
\hline Qatar & 3 & 2 & 0 & 0 & 5 \\
\hline Saudi Arabia & 0 & 0 & 0 & 0 & 0 \\
\hline Somali & 0 & 0 & 0 & 0 & 0 \\
\hline Sudan & 0 & 0 & 0 & 0 & 0 \\
\hline Syria & 3 & 0 & 0 & 0 & 3 \\
\hline Tunisia & 1 & 0 & 0 & 0 & 1 \\
\hline UAE & 0 & 0 & 0 & 0 & 0 \\
\hline Yemen & 3 & 0 & 0 & 0 & 3 \\
\hline Max. score & 4 & 2 & 1 & 3 & 10 \\
\hline
\end{tabular}

Large direct health warning labels: ${ }^{a}$ Size of warning (one only of): $\leq 10 \%$ of packet $=1,11 \%-25 \%$ of packet $=2,26 \%-40 \%$ of packet $=3, \geq 41 \%$ or more of packet $=4$. ${ }^{b}$ Rotating health warnings $=2 .{ }^{c}$ Contrasting colour (e.g. black lettering on white background) $=1$. ${ }^{d}$ Picture $=3$. Source: MPOWER, 2008 [4]. 


\begin{tabular}{|c|c|c|c|c|c|c|c|}
\hline \multirow[t]{2}{*}{ Country } & \multirow{2}{*}{$\begin{array}{l}\text { Nicotine } \\
\text { available }^{\mathrm{a}}\end{array}$} & \multirow{2}{*}{$\begin{array}{l}\text { Bupropion } \\
\text { available }^{\mathrm{b}}\end{array}$} & \multicolumn{4}{|c|}{ Smoking cessation support available: } & \multirow{2}{*}{$\begin{array}{l}\text { Total } \\
\text { score }\end{array}$} \\
\hline & & & $\begin{array}{l}\text { Primary } \\
\text { care }^{\mathrm{c}}\end{array}$ & Hospitals $^{\mathrm{d}}$ & $\begin{array}{c}\text { Health } \\
\text { professionals }\end{array}$ & Community ${ }^{f}$ & \\
\hline Afghanistan & 1 & 0 & 0 & 0 & 0 & 0 & 1 \\
\hline Bahrain & 1 & 1 & 1 & 1 & 1 & 0 & 5 \\
\hline Djibouti & 1 & 1 & 0 & 0 & 0 & 0 & 2 \\
\hline Egypt & 1 & 0 & 1 & 1 & 0 & 0 & 3 \\
\hline Iran (IR) & 1 & 1 & 1 & 1 & 1 & 1 & 6 \\
\hline Iraq & 1 & 0 & 0 & 0 & 0 & 0 & 1 \\
\hline Jordan & 1 & 0 & 1 & 0 & 0 & 1 & 3 \\
\hline Kuwait & 1 & 0 & 2 & 2 & 2 & 2 & 9 \\
\hline Lebanon & 1 & 1 & 0 & 1 & 1 & 0 & 4 \\
\hline Libya & 0 & 0 & 0 & 0 & 0 & 0 & 0 \\
\hline Morocco & 1 & 1 & 2 & 1 & 1 & 0 & 6 \\
\hline Oman & 1 & 0 & 0 & 0 & 0 & 0 & 1 \\
\hline Pakistan & 0 & 0 & 0 & 0 & 0 & 0 & 0 \\
\hline Qatar & 1 & 0 & 1 & 1 & 1 & 1 & 5 \\
\hline Saudi Arabia & 0 & 0 & 0 & 0 & 0 & 0 & 0 \\
\hline Somalia & 0 & 0 & 0 & 0 & 0 & 0 & 0 \\
\hline Sudan & 0 & 0 & 1 & 0 & 0 & 0 & 1 \\
\hline Syria & 1 & 0 & 2 & 2 & 2 & 2 & 9 \\
\hline Tunisia & 1 & 0 & 2 & 2 & 2 & 2 & 9 \\
\hline UAE & 1 & 0 & 0 & 0 & 0 & 0 & 1 \\
\hline Yemen & 0 & 0 & 0 & 0 & 0 & 0 & 0 \\
\hline Max. score & 1 & 1 & 2 & 2 & 2 & $2^{a}$ & 10 \\
\hline
\end{tabular}

${ }^{a}$ Nicotine replacement available $=1 .{ }^{b}$ Bupropion available $=1$. ${ }^{c}$ Smoking cessation support available in primary care facilities: no $=0$, yes in some $=1$, yes in most $=2$. ${ }^{d}$ Smoking cessation support available in hospitals: $n o=0$, yes in some $=1$, yes in most $=2 .{ }^{e}$ Smoking cessation support available from health professionals: $n o=0$, yes in some $=1$, yes in most $=2 .{ }^{f}$ Smoking cessation support available in the community: $n o=0$, yes in some =1, yes in most $=2$. Source: MPOWER, 2008 [4].

\begin{tabular}{|c|c|c|c|c|c|c|c|}
\hline Country & Price & Public place ban & Budget & Advert ban & Health warnings & Treatment & Total tobacco control score \\
\hline Iran (IR) & 6 & 11.0 & 15 & 13.0 & 10 & 6 & 61.0 \\
\hline Jordan & 18 & 5.6 & 11 & 10.5 & 7 & 3 & 55.1 \\
\hline Egypt & 17 & 4.2 & 9 & 10.5 & 8 & 3 & 51.7 \\
\hline Syria & 12 & 0.0 & 12 & 12.0 & 3 & 9 & 48.0 \\
\hline Yemen & 21 & 2.8 & 10 & 6.5 & 3 & 0 & 43.3 \\
\hline Tunisia & 24 & 0.0 & - & 9.2 & 1 & 9 & 43.2 \\
\hline Pakistan & 25 & 2.8 & 13 & 0.0 & 0 & 0 & 40.8 \\
\hline Kuwait & 2 & 9.0 & 8 & 9.0 & 0 & 9 & 37.0 \\
\hline Sudan & 24 & 0.0 & 5 & 0.9 & 0 & 1 & 30.9 \\
\hline Morocco & 24 & 0.0 & - & 0.0 & 0 & 6 & 30.0 \\
\hline Afghanistan & 26 & 0.0 & - & 0.0 & 0 & 0 & 26.0 \\
\hline Djibouti & - & 0.0 & 4 & 11.7 & 8 & 2 & 25.7 \\
\hline Bahrain & 13 & 4.2 & - & 1.2 & 0 & 5 & 23.4 \\
\hline Qatar & 2 & 0.0 & 3 & 8.0 & 5 & 5 & 23.0 \\
\hline Saudi Arabia & 4 & 0.0 & 14 & 3.5 & 0 & 0 & 21.5 \\
\hline Oman & 2 & 11.2 & 6 & 0.0 & 0 & 1 & 20.2 \\
\hline Lebanon & 7 & 0.0 & 7 & 0.0 & 0 & 4 & 18.0 \\
\hline Iraq & 11 & 0.0 & - & 0.0 & 0 & 1 & 12.0 \\
\hline UAE & 2 & 4.2 & - & 4.0 & 0 & 1 & 11.2 \\
\hline Libya & - & 1.4 & - & 0.0 & 0 & 0 & 1.4 \\
\hline Somalia & - & 1.2 & - & 0.0 & 0 & 0 & 1.2 \\
\hline Max. score & 30 & 22.0 & 15 & 13.0 & 10 & 10 & 100.0 \\
\hline
\end{tabular}




\section{References}

1. WHO Framework convention on tobacco control [online]. World Health Organization (http://www.who.int/tobacco/ framework/en, accessed 20 May 2012).

2. Hill DJ, White VM, Scollo MM. Smoking behaviours of Australian adults in 1995: trends and concerns. Medical Journal of Australia, 1998, 168:209-213.

3. Joossens L, Raw M. The Tobacco Control Scale: a new scale to measure country activity. Tobacco Control, 2006, 15:247-253.
4. WHO report on the global tobacco epidemic, 2008: The MPOWER package. Geneva, World Health Organization, 2008.

5. Mackay J et al., eds. The tobacco atlas, 3rd ed. Atlanta, Georgia, American Cancer Society and World Lung Foundation, 2009.

6. World development report 2008: agriculture for development. Washington DC, World Bank, 2008.

\section{Tobacco Free Initiative}

The regional Tobacco Free Initiative seeks to strengthen the implementation of the WHO Framework Convention on Tobacco Control (FCTC), as well as to change public opinion and social norms regarding tobacco. Comprehensive tobacco control measures are outlined in the WHO FCTC. This includes tobacco demand reduction, supply reduction and other measures to be implemented by governments. Guidelines to the Convention provide Parties with guidance on introducing and enforcing these comprehensive tobacco control measures.

Demand reduction measures include: price and tax measures; non-price measures; protection from exposure to tobacco smoke; regulation of the contents of tobacco products; regulation of tobacco product disclosures; packaging and labelling of tobacco products; education, communication, training and public awareness; tobacco advertising, promotion and sponsorship; measures concerning tobacco dependence and cessation.

Supply reduction measures include: tackling the illicit trade in tobacco products; banning sale to and by minors; provision of support for economically-viable alternatives.

Other measures relate to: protection of the environment; liability; scientific and technical cooperation; communication of information; institutional arrangements and financial resources; settlement of disputes; and development of the Convention and final provisions.

Further information about the regional Tobacco Free Initiative is available at: http://www.emro.who.int/entity/ tobacco-free-initiative/ 